Utoguchi, N., Magnusson, M., and Audus, K.L. (1999) Carrier-mediated transport of monocarboxylic acids in BeWo cell monolayers as a model of the human trophoblast. J. Pharm. Sci. 88, 1288-1292. PMID: 10585224. Publisher's official version: <http://dx.doi.org/10.1021/js990173q>. Open Access version: http://kuscholarworks.ku.edu/dspace/.

[This document contains the author's accepted manuscript. For the publisher's version, see the link in the header of this document.]

Paper citation: Utoguchi, N., Magnusson, M., and Audus, K.L. (1999) Carrier-mediated transport of monocarboxylic acids in BeWo cell monolayers as a model of the human trophoblast. J. Pharm. Sci. 88, 1288-1292. PMID: 10585224

\begin{abstract}
The monolayer-forming, human choriocarcinoma cell line, BeWo, was used to study the mechanisms of monocarboxylic acid transport across the human trophoblast. Benzoic acid, acetic acid, and lactic acid were used as markers for monocarboxylic acid carrier-mediated transport. The uptake of benzoic acid by BeWo cells was saturable $\left(\mathrm{K}_{\mathrm{t}}=0.6 \pm 0.3 \mathrm{mM}\right)$ at higher concentrations and significantly inhibited by typical metabolic inhibitors, sodium azide and 2,4-dinitrophenol. A selection of different monocarboxylic acids, including a natural substrate lactic acid, also substantially inhibited the uptake of benzoic acid and acetic acid by BeWo cells, whereas dicarboxylic acids did not affect the uptake of either marker. Monocarboxylic acid uptake was $\mathrm{pH}$-dependent and inhibited by carbonylcyanide $p$ trifluoromethoxyphenylhydrazone (FCCP), a protonophore. Kinetic analysis using LineweaverBurk plots revealed that monocarboxylic acids competitively inhibited the uptake of benzoic, lactic, and acetic acid by BeWo cells. In transport experiments, the permeation of benzoic acid from apical-to-basolateral side was greater than the permeation from the basolateral-to-apical side, and the transport of benzoic acid from apical-to-basolateral side was inhibited by monocarboxylic acids. The findings obtained in the present study confirm the existence of an asymmetric, carrier-mediated transport system for monocarboxylic acids across the BeWo cell, a representative of the human trophoblast.
\end{abstract}

Text of paper:

\title{
CARRIER-MEDIATED TRANSPORT OF MONOCARBOXYLIC ACIDS IN BEWO CELL MONOLAYERS AS A MODEL OF THE HUMAN TROPHOBLAST
}

\author{
NAOKI UTOGUCHI ${ }^{1}$, MALIN MAGNUSSON ${ }^{2}$, AND KENNETH L. AUDUS $^{2,3}$
}

\section{Present address: Showa College of Pharmaceutical Sciences, Machida, Tokyo 194-8543, Japan}

2 Department of Pharmaceutical Chemistry, The University of Kansas, Lawrence, Kansas 66047 Tel: 785-864-4138, Fax: 785-864-5736

3 Correspondence to: Kenneth L. Audus, Ph.D., Department of Pharmaceutical Chemistry, The University of Kansas, 2095 Constant Avenue, Lawrence , Kansas 66047. Tel: 785-864-4138, Fax: 785-864-5736. E-mail: audus@ukans.edu 
Utoguchi, N., Magnusson, M., and Audus, K.L. (1999) Carrier-mediated transport of monocarboxylic acids in BeWo cell monolayers as a model of the human trophoblast. J. Pharm. Sci. 88, 1288-1292. PMID: 10585224. Publisher's official version: <http://dx.doi.org/10.1021/js990173q> . Open Access version: http://kuscholarworks.ku.edu/dspace/.

\section{INTRODUCTION}

The placenta, in part, serves as a semipermeable barrier separating the maternal and fetal circulations. The placental barrier is comprised of a single layer of trophoblasts that have an important role in controlling the passage of molecules from mother to fetus. In general, the absorption of drugs across the single layer of trophoblasts can be explained in terms of the $\mathrm{pH}$-partition hypothesis which is well illustrated by passive diffusion mechanisms. ${ }^{1,2}$ However, with the use of brush-bordermembrane vesicle techniques or cultured cells ${ }^{3}$, it has become increasingly clear that there are a number of carrier-mediated transport mechanisms present at the placental barrier including systems for amino acids ${ }^{3,4}$, transferrin ${ }^{5}$, and dopamine ${ }^{6}$. These carriers take on pharmaceutical relevance due to the fact that nutrients, hormones, as well as, drugs and drugs of abuse can be transported across the placental barrier by these mechanisms. ${ }^{7}$

Carrier-mediated transport mechanisms for monocarboxylic acids exist in many cell types. ${ }^{8-10}$ In fact, there are known to be at least seven putative monocarboxylic acid transporter (MCT) isoforms. The mRNA representing five of the seven MCTs has been shown in human placenta ${ }^{11}$. Using brush border membrane preparations, a functional, proton-dependent MCT has been observed in tissues from rat ${ }^{12,13}$ and human ${ }^{14}$ placenta. A functional, bidirectional, and carrier-mediated mechanism for lactic acid, presumably a $\mathrm{MCT}$, has also been demonstrated in the perfused human placental lobe model ${ }^{15}$. In addition to the transport of lactic acid, ${ }^{11,14,15}$ a MCT at the placental barrier presents a potential mechanism by which monocarboxylic acid drugs and drugs of abuse may readily distribute between maternal and fetal compartments. Therefore, the 
Utoguchi, N., Magnusson, M., and Audus, K.L. (1999) Carrier-mediated transport of monocarboxylic acids in BeWo cell monolayers as a model of the human trophoblast. J. Pharm. Sci. 88, 1288-1292. PMID: 10585224. Publisher's official version: <http://dx.doi.org/10.1021/js990173q>. Open Access version: http://kuscholarworks.ku.edu/dspace/.

characterization of a placental MCT system can contribute to an understanding of the trophoblast transport mechanisms controlling fetal exposure to substances possessing a monocarboxylic acid constituent.

The objective of this study was to investigate the presence of a functional MCT in BeWo cell monolayers, a representative human trophoblast culture system. ${ }^{16}$ BeWo cell monolayers have been applied to studies of the polarized trans-trophoblast transport of serotonin and transferrin, monoamine uptake processes, and relevant nutrient uptake and transport systems. ${ }^{16-18}$ The existence of MCT systems in the BeWo cells would provide an in vitro tool representative of the human trophoblast to characterize trans-placental transport mechanisms that influence drug distribution in pregnancy. The BeWo cell line is particularly attractive for the studies of drug distribution at the placenta barrier because it is stable, relatively easy to maintain by passage, and grows to a confluent monolayer in relatively short period of time. Indeed, in contrast to primary cultures, the cell line is one of the few existing trophoblast cell culture systems to form a confluent monolayer that allows trans-trophoblast transport studies. More importantly, the BeWo cell displays morphological properties and biochemical marker enzymes and hormone secretion common to normal trophoblasts. ${ }^{16}$

\section{MATERIALS AND METHODS}

Materials. $\left[{ }^{14} \mathrm{C}\right]$ Benzoic acid $(55 \mathrm{Ci} / \mathrm{mol}),\left[{ }^{14} \mathrm{C}\right]$-L-lactic acid $(150 \mathrm{Ci} / \mathrm{mmol})$, and $\left[{ }^{14} \mathrm{C}\right]$ acetic acid $(55 \mathrm{Ci} / \mathrm{mol})$ were obtained from American Radiolabeled Chemicals (St. Louis, MO). Fetal bovine serum (FBS) was from JRH Bioscience (Lenexa, KS). Penicillin-streptomycin as a mixture was from Gibco (Gaithersburg, MD). Translucent 
Utoguchi, N., Magnusson, M., and Audus, K.L. (1999) Carrier-mediated transport of monocarboxylic acids in BeWo cell monolayers as a model of the human trophoblast. J. Pharm. Sci. 88, 1288-1292. PMID: 10585224. Publisher's official version: <http://dx.doi.org/10.1021/js990173q> . Open Access version: http://kuscholarworks.ku.edu/dspace/.

polycarbonate filters (13 $\mathrm{mm}$ diameter, $0.4 \mu \mathrm{m}$ pore size) were purchased from Fisher Scientific. All other chemicals were of the purest available analytical grade and purchased from Fisher or Sigma (St. Louis, MO).

Cell Culture. The BeWo cell line was originally derived from a human choriocarcinoma. The BeWo clone (b30) was obtained from Dr. Alan Schwartz (Washington University, St. Louis, MO). The cells were cultured by the methods previously described and the cells used in these experiments were from passages 28 to $40 .{ }^{16}$. Briefly, the cells were cultured in Dulbecco's modified Eagle's medium (DMEM) with $10 \%$ heat-inactivated FBS containing $0.37 \%$ sodium bicarbonate and $1 \%$ antibiotics $(10,000 \mathrm{U} / \mathrm{ml}$ penicillin and $10 \mathrm{mg} / \mathrm{ml}$ streptomycin). The cells were maintained in $175-\mathrm{cm}^{2}$ flasks at $\mathrm{pH} 7.4$ under $5 \% \mathrm{CO}_{2}$ and $95 \%$ humidity at $37^{\circ} \mathrm{C}$. The cells were harvested by exposure to a trypsin-EDTA solution (0.25\% trypsin and $0.02 \%$ EDTA in HBSS) and passed onto 12-well tissue culture plates or polycarbonate membranes coated with rat tail collagen in $100-\mathrm{mm}$ culture dishes. With the seeding density of 10,000 cells $/ \mathrm{cm}^{2}$, the cells formed confluent monolayers between 2 and 3 days and were used for experiments at that time.

Uptake Experiments. The BeWo cells at confluence were washed twice with Hank's balanced salt solution (HBSS; $136.7 \mathrm{mM} \mathrm{NaCl}, 0.385 \mathrm{mM} \mathrm{Na}_{2} \mathrm{HPO}_{4}, 0.441 \mathrm{mM}$ $\mathrm{KH}_{2} \mathrm{PO}_{4}, 0.952 \mathrm{mM} \mathrm{CaCl}_{2}, 5.36 \mathrm{mM} \mathrm{KCl}, 0.812 \mathrm{mM} \mathrm{MgSO}_{4}, 25 \mathrm{mM}$ D-glucose and 10 mM HEPES (2-[4-(2-Hydroxyethyl)-1-piperazinyl]ethanesulfonic acid) for adjustment to pH 7.0 or 7.5 or 10 mM MES (2-morpholinoethanesulfonic acid, monohydrate) for adjustment to $\mathrm{pHs}<6.5$ and then the test solution containing $\left[{ }^{14} \mathrm{C}\right]$ benzoic acid or $\left[{ }^{14} \mathrm{C}\right]$ acetic acid or $\left[{ }^{14} \mathrm{C}\right]$-L-lactic acid was added at $0.25 \mu \mathrm{Ci} / \mathrm{ml}$ as a marker for 
Utoguchi, N., Magnusson, M., and Audus, K.L. (1999) Carrier-mediated transport of monocarboxylic acids in BeWo cell monolayers as a model of the human trophoblast. J. Pharm. Sci. 88, 1288-1292. PMID: 10585224. Publisher's official version: <http://dx.doi.org/10.1021/js990173q> . Open Access version: http://kuscholarworks.ku.edu/dspace/.

monocarboxylic acid carrier-mediated transport. The $\mathrm{pH}$ of the test solution was 6.0 except in the $\mathrm{pH}$-dependent uptake experiments. After $30 \mathrm{~s}$, the test solution was aspirated away and the cells were washed with ice-cold HBSS three times. For quantitation of drug uptake, the cells were suspended in $1.0 \mathrm{~N} \mathrm{NaOH}$ and the suspension was incubated at $37^{\circ} \mathrm{C}$ overnight at which point, a half volume of $2.0 \mathrm{~N} \mathrm{HCl}$ was added. Radioactivity was quantitated using a liquid scintillation counter. Cellular protein was quantified using a protein assay kit (Pierce) with bovine serum albumin as a standard. Details of the conditions for each experiment are given in the Figure Legends or Table Footnotes.

In one series of experiments, an equivalent amount of choline chloride replaced sodium chloride in the HBSS and was used as a sodium-depleted buffer.

Transport Experiment. A horizontal Side-Bi-Side diffusion apparatus (Crown Glass) was used to measure the transmonolayer permeability of cells grown on the surface of $0.4 \mu \mathrm{m}$ pored polycarbonate filters, as previous described. ${ }^{16}$ The cells faced the donor chamber as the apical side, and the polycarbonate membrane faced the receiver chamber as the basolateral side. The water jacket surrounding the donor and the receiver chambers was thermostated $a 7^{\circ} \mathrm{C}$. The contents of each chamber were continuously stirred at $600 \mathrm{rpm}$ with magnetic stir bars. When the apical-to-basolateral transport studies were performed, the $\mathrm{pH}$ of the donor (apical) side was 6.0 and that of receptor (basolateral) side was 7.4. When the basolateral-to-apical transport studies were performed, the $\mathrm{pH}$ of the donor (basolateral) side was 6.0 and that of receptor (apical) side was 7.4. The concentration of added $\left[{ }^{14} \mathrm{C}\right]$ benzoic acid was $0.25 \mu \mathrm{Ci} / \mathrm{ml}$. A 0.2-ml aliquot from the receiver chamber was taken at several time points up to $60 \mathrm{~min}$. 


\section{Calculation of Apparent Permeability Coefficients. Apparent permeability}

coefficients for the monolayers of cells, $\mathrm{P}_{\mathrm{e}}$, were calculated from the following relationship

$$
1 / P_{t}=1 / P_{e}+1 / P_{m}
$$

where $P_{t}$ is apparent permeability coefficient for the collage-coated membrane in the presence of monolayers, and $\mathrm{P}_{\mathrm{m}}$ is the apparent permeability coefficient for collagencoated polycarbonate membrane alone. ${ }^{19}$

Michaelis-Menten Parameters. To estimate the values of the kinetic parameters of saturable uptake by BeWo cells, the uptake rate $(\mathrm{J})$ was fitted to the following equation, which consists of both saturable and nonsaturable linear terms, using a nonlinear least-squares regression analysis program MULTI: ${ }^{20}$

$$
\mathrm{J}=\mathrm{J}_{\max } \times \mathrm{C} /\left(\mathrm{K}_{\mathrm{t}}+\mathrm{C}\right)+\mathrm{k} \times \mathrm{C} \quad \text { Eq. (2) }
$$

where $\mathrm{J}_{\max }$ is the maximum uptake rate for a carrier-mediated process, $\mathrm{C}$ is the benzoic acid concentration, $\mathrm{K}_{\mathrm{t}}$ is the half-saturation concentration (Michaelis constant), and $\mathrm{k}$ is a first-order rate constant.

Statistical Analysis. All results were expressed as means \pm standard deviation (SD). Statistical analysis between two groups was performed using Student's t-test, and one-way analysis of variance (ANOVA) was used for single and multiple comparisons. $P$ values of 0.05 or less were considered to indicate a statistically significant difference.

\section{RESULTS}

$\left[{ }^{14} \mathrm{C}\right]$ Benzoic acid was rapidly accumulated in BeWo cells with time (Figure 1). The uptake was linear initially and reached equilibrium at about 2 min. Therefore, all 
Utoguchi, N., Magnusson, M., and Audus, K.L. (1999) Carrier-mediated transport of monocarboxylic acids in BeWo cell monolayers as a model of the human trophoblast. J. Pharm. Sci. 88, 1288-1292. PMID: 10585224. Publisher's official version: <http://dx.doi.org/10.1021/js990173q> . Open Access version: http://kuscholarworks.ku.edu/dspace/.

subsequent uptake studies and kinetic analysis were performed from data collected through $30 \mathrm{~s}$.

Figure 2 shows the relationship between the initial rate of uptake of $\left[{ }^{14} \mathrm{C}\right]$ benzoic acid and its concentration in the incubation buffer. The results indicated that the uptake of benzoic acid consisted of two processes, a saturable process evident at low concentrations and an apparently nonsaturable process evident at high concentrations. The uptake processes were analyzed according to Eq. (2). The kinetic parameters calculated for benzoic acid uptake were a $J_{\max }$ of $0.52 \pm 0.22 \mathrm{nmol} / 30 \mathrm{~s} / \mathrm{mg}$ of protein, a $\mathrm{K}_{\mathrm{t}}$ of $0.64 \pm 0.26 \mathrm{mM}$, and a $\mathrm{k}$ of $0.11 \pm 0.06 \mu \mathrm{l} / 30 \mathrm{~s} / \mathrm{mg}$ of protein. The upper dotted line represents the uptake for the saturable component calculated from the kinetic parameters. The lower dotted line represents the uptake for the nonsaturable component calculated from the kinetic parameters. At any given concentration, the uptake by saturable component was higher than that by nonsaturable one.

The effects of metabolic inhibitors on the uptake of $\left[{ }^{14} \mathrm{C}\right]$ benzoic acid were studied to determine whether this uptake required cell-dependent energy expenditure (Table 1). Sodium azide (10 mM), a respiratory chain inhibitor, or 2,4-dinitrophenol (1 $\mathrm{mM}$ ), an uncoupler of oxidative phosphorylation, significantly inhibited the uptake of $\left[{ }^{14} \mathrm{C}\right]$ benzoic acid by the BeWo cells. Moreover, carbonylcyanide $p$ trifluoromethoxyphenylhydrazone (FCCP; $50 \mu \mathrm{M})$, a protonophore, significantly inhibited the uptake (Table 1), whereas 4,4'-diisothiocyanostilbene-2,2'-disulfonic acid (DIDS; 0.1 $\mathrm{mM})$, an anion-exchange inhibitor, had no inhibitory effect on benzoic acid uptake. Finally, the uptake of benzoic acid in a sodium-depleted buffer was not different from the control suggesting the mechanism was not sodium-dependent (Table1). Figure 3 
illustrates the effect of incubation buffer $\mathrm{pH}$ in the range from 5.0 to 7.5 on $\left[{ }^{14} \mathrm{C}\right]$ benzoic acid uptake by BeWo cells. The rate of $\left[{ }^{14} \mathrm{C}\right]$ benzoic acid uptake decreased with increasing $\mathrm{pH}$ from an acidic to a neutral $\mathrm{pH}$. These findings, together with the concentration dependence and sensitivity to metabolic inhibitors, strongly suggested that $\left[{ }^{14} \mathrm{C}\right]$ benzoic acid uptake by BeWo cells was dependent on a proton gradient and was carrier-mediated.

To investigate the properties of the carrier involved in $\left[{ }^{14} \mathrm{C}\right]$ benzoic acid uptake by BeWo cells, we studied the effects of various mono- and di- carboxylic acids on this uptake (Table 2). Each monocarboxylic acid, including lactic acid, significantly inhibited the uptake of $\left[{ }^{14} \mathrm{C}\right]$ benzoic acid, whereas none of the dicarboxylic acids had a significant inhibitory effect on the uptake of the marker. We also found that the BeWo cells take up $\left[{ }^{14} \mathrm{C}\right]$ acetic acid and that this uptake was significantly inhibited by monocarboxylic acids, including lactic acid (Table 2). In contrast, dicarboxylic acids had no marked effect on the uptake of $\left[{ }^{14} \mathrm{C}\right]$ acetic acid by BeWo cells. These results implied that the carrier that mediates monocarboxylic acid uptake by BeWo cells was a nonspecific monocarboxylic acid carrier. Additionally, the carrier is relatively stereoselective as distinguished by the variable inhibition by the two lactic acid isomers

To study the mechanism of the benzoic acid or acetic acid or lactic acid uptake inhibition by the monocarboxylic acids, we analyzed the inhibitory effect kinetically. Figure 4A shows a Lineweaver-Burk plot for the uptake of $\left[{ }^{14} \mathrm{C}\right]$ benzoic acid by BeWo cells in the absence or presence of $2 \mathrm{mM}$ acetic acid. Acetic acid competitively inhibited the uptake of benzoic acid by the BeWo cells. Figure 4B shows a Lineweaver-Burk plot for the uptake of $\left[{ }^{14} \mathrm{C}\right]$ acetic acid by BeWo cells in the absence or presence of $2 \mathrm{mM}$ 
Utoguchi, N., Magnusson, M., and Audus, K.L. (1999) Carrier-mediated transport of monocarboxylic acids in BeWo cell monolayers as a model of the human trophoblast. J. Pharm. Sci. 88, 1288-1292. PMID: 10585224. Publisher's official version: <http://dx.doi.org/10.1021/js990173q> . Open Access version: http://kuscholarworks.ku.edu/dspace/.

benzoic acid. Similarly, Figures 4C and 4D confirm that lactic acid and benzoic acid interact with the BeWo uptake mechanism by a competitive process. Table 3

summarizes the kinetic data and indicates that the $\mathrm{K}_{\mathrm{m}}$ 's and $\mathrm{K}_{i}$ 's for benzoic, acetic, and lactic acid for the apparent moncarboxylic acid uptake mechanism were similar.

The trans-trophoblast passage of $\left[{ }^{14} \mathrm{C}\right]$ benzoic acid across the BeWo monolayer was found to be asymmetric, with the permeability coefficient greater in the apical-tobasolateral direction than that in the basolateral-to-apical direction, as shown in Table 4 . The passage of $\left[{ }^{14} \mathrm{C}\right]$ benzoic acid across the BeWo monolayers was inhibited by an excess amount of unlabeled benzoic acid or other monocarboxylic acid (valproic acid) as shown in Table 4, affirming that the transcellular passage of the monocarboxylic acid appeared similar to the uptake process.

\section{DISCUSSION}

Passive diffusion is the primary mechanism by which xenobiotics cross the placental barrier. ${ }^{1}$ However, some carrier-mediated transport systems in the trophoblast have been described using brush-border membrane vesicles or cultured cells, ${ }^{3,5,6}$ including functional MCTs. ${ }^{12-14}$ These carrier systems are notable for mediating the distribution of both endogenous and exogenous substances across the placental barrier. ${ }^{7}$ Recent studies in knockout mice have effectively illustrated the relevance of placental transport mechanisms, e.g., P-glycoprotein, in protecting the fetus from exposure to chemicals. ${ }^{21}$ Consequently, the recognition of transport mechanisms is important for developing an understanding of the molecular mechanisms and role of the trophoblast in regulating drug passage across the placental barrier. 
Utoguchi, N., Magnusson, M., and Audus, K.L. (1999) Carrier-mediated transport of monocarboxylic acids in BeWo cell monolayers as a model of the human trophoblast. J. Pharm. Sci. 88, 1288-1292. PMID: 10585224. Publisher's official version: <http://dx.doi.org/10.1021/js990173q>. Open Access version: http://kuscholarworks.ku.edu/dspace/.

There is also a critical need for in vitro systems of human origin that allow characterization of mechanisms regulating drug distribution between mother and fetus to aid in the future design and development of drugs that can be safely administered in pregnancy. ${ }^{22,23}$

In the present study, we used benzoic acid uptake and transport, as a marker for the monocarboxlic acid transport ${ }^{8}$ in BeWo cell monolayers. The establishment of functional MCT mechanisms in the BeWo cells offers the opportunity to characterize mechanisms of monocarboxylic acid transport at the molecular and biochemical level, extending limited studies performed with brush border preparations ${ }^{12-14}$ and the perfused human placental lobe. ${ }^{15}$

The processing of benzoic acid by the BeWo monolayers was characterized by saturable uptake and transport. The processes were significantly inhibited by metabolic inhibitors and indicated that benzoic acid uptake is energy dependent. Benzoic acid transport and uptake were also significantly inhibited by in a competitive manner by unlabeled benzoic acid, acetic acid, and lactic acid. Further, benzoic acid uptake and transport were significantly inhibited by monocarboxylic acids but not selected dicarboxylic acids. The competitive nature of the transport, evidenced by the kinetic parameters, was consistent with observations reported for the transport of monocarboxylic acids in placental brush border vesicles. ${ }^{12-14}$

The advantage of the BeWo monolayer system is that trans-trophoblast transport properties can be characterized in a polarized cell. ${ }^{16}$ We were able to show the passage of benzoic acid across the BeWo monolayers was bidirectional and of a faster rate going in the apical-to-basolateral side direction across the monolayers in the 
Utoguchi, N., Magnusson, M., and Audus, K.L. (1999) Carrier-mediated transport of monocarboxylic acids in BeWo cell monolayers as a model of the human trophoblast. J. Pharm. Sci. 88, 1288-1292. PMID: 10585224. Publisher's official version: <http://dx.doi.org/10.1021/js990173q> . Open Access version: http://kuscholarworks.ku.edu/dspace/.

presence of a pH gradient. These observations are in good agreement with the lactate transport studies performed in the perfused human placental lobe model. ${ }^{15}$ Further, our studies suggested a functional asymmetry in the carrier mechanism.

Caco-2 cells, which are a well-characterized model of the intestinal epithelium, possess a monocarboxylic acid transport system which is $\mathrm{pH}$ dependent. ${ }^{8}$ The activation of benzoic acid uptake by acidic $\mathrm{pH}$ can be explained by $\mathrm{H}+$ cotransport, $\mathrm{OH}-$ exchange system, or a possible change in affinity to the carrier protein depending on the extracellular $\mathrm{pH}$. The uptake of benzoic acid by BeWo monolayers increased with a decreased $\mathrm{pH}$. The lack of an inhibitory effect of DIDS, an inhibitor of anion exchange, suggests that an $\mathrm{OH}$ - exchange system with benzoic acid was not involved in uptake or transport by BeWo cells. Many types of transporters are Na+ dependent. However, benzoic acid uptake by BeWo cells was also not inhibited in the Na+-depleted buffer in this study. Benzoic acid is an acidic compound; therefore, a decrease in $\mathrm{pH}$ increases the fraction of nonionized benzoic acid. According to the $\mathrm{pH}$-partition hypothesis, this increase in the fraction of nonionized form increases the passive accumulation of benzoic acid across the BeWo cell membrane. Data presented here (e.g., Figure 3), and other studies conducted in absence of $\mathrm{pH}$ gradients, where the rate of transfer and asymmetry of transport for representative monocarboxylic acid drugs (e.g, acetylsalicylic acid and ibuprofen) is substantially diminished (data not shown), are alone insufficient to conclude that the uptake of benzoic acid is proton-gradientdependent. However, the need for a proton gradient was affirmed with our results that showed FCCP, a protonophore, strongly inhibited the uptake of benzoic acid. Collectively then, our results indicated that monocarboxylic acid uptake was proton- 
Utoguchi, N., Magnusson, M., and Audus, K.L. (1999) Carrier-mediated transport of monocarboxylic acids in BeWo cell monolayers as a model of the human trophoblast. J. Pharm. Sci. 88, 1288-1292. PMID: 10585224. Publisher's official version: <http://dx.doi.org/10.1021/js990173q>. Open Access version: http://kuscholarworks.ku.edu/dspace/.

gradient-dependent and were entirely consistent with similar studies conducted with human trophoblast brush border membrane preparations. ${ }^{14}$ From a pharmacological and physiological perspective, this is significant since a pH gradient does develop across the placenta with advancing pregnancy. The developing $\mathrm{pH}$ gradient does influence drug distribution across the placenta ${ }^{24}$ and may possibly influence the MCT carrier's role in regulating the distribution of monocarboxylic acids between the mother and fetus. The physiological role of a MCT in the trophoblast is likely related to the regulation of the distribution of L-lactic acid and related substrates across the placental barrier. $^{14,15}$

Monocarboxylic acids are transported out of muscle and into liver (i.e., the socalled Cori cycle) by proton-coupled transporters, MCTs, that exhibited distinct substrate specificities and could be differentially inhibited by $\alpha$-cyanocinnamates. MCT1 isolated from a Chinese hamster ovary cell cDNA library, is found in cardiac muscle, erythrocytes, basolateral intestinal epithelium, and skeletal muscle. MCT2, cloned from hamster liver, is functionally similar to MCT1 in terms of transport capabilities, but its tissue distribution is significantly different. ${ }^{25} \mathrm{~A}$ third transporter isoform, MCT3, was identified in chick retinal pigment epithelium. More recently, four new MCT homologs have been cloned and sequenced in human tissue (MCT3MCT7). ${ }^{11}$ There is currently no direct information of the type of functional MCTs associated with BeWo cells or human trophoblasts. Thus, further studies with molecular probes and selective substrates, when available, will be required to precisely identify which of the seven monocarboxylic acid transporter isoforms may be present in the 
human placental barrier. Elucidating the precise forms of functional MCTs in the trophoblast remains an ongoing objective of our laboratory.

In summary, our present results support limited evidence in the literature ${ }^{12-15}$ that monocarboxylic acids and nutrients, drugs, drugs of abuse and other xenobiotics that have a monocarboxylic acid constituent have the potential to be substrates for protongradient-dependent transport across the human trophoblast. This work further demonstrates the possible utility of a human, monolayer-forming cell line, BeWo, to characterize putative trans-trophoblast transport mechanisms and their potential roles in controlling nutrients, drugs, and drugs of abuse distribution across the placental barrier.

\section{Acknowledgements}

This work was supported by a grant from National Institute of Drug Abuse (NIDA N01DA-4-7405). The authors would also like to acknowledge the support of Corning Costar Corporation for support of the Cellular and Molecular Biopharmaceutics Handling Laboratory. 


\section{References}

1. Stulc, J. Extracellular transport pathways in the haemochrorial placenta.

Placenta $1989,15,113-119$.

2. Hay, Jr., W. W. Placental transport of nutrients to the fetus. Horm. Res. 1994, 42, 215-222.

3. Kubo, Y.; Yamada, K.; Fujiwara, A.; Kawasaki, T. Characterization of amino acid transport systems in human placental brush-border membrane vesicles. Biochem. Biophy. Acta 1987, 904,309-318.

4. Yudilevich, D. L.; Sweiry, J. H. Transport of amino acids in the placenta. Biochem. Biophy. Acta 1985, 822, 169-201.

5. Cerneus, D. P.; Van der Ende, A. Apical to basolateral transferrin receptors in polarized BeWo cells recycle through separate endosomes. J. Cell Biol. 1991, 114, 1149-1158.

6. Ramamoorthy, S.; Leibach, F.H.; Mahesh, V.B.; Ganapathy, V. Active transport of dopamine in human placental brush border membrane vesicles. Am. J. Physiol. 1992, 262, C1189-C1196 
7. Ganapathy, V.; Prasad, P.D.; Ganapathy, M.E.; Leibach, F.H. Drugs of abuse and placental transport. Adv. Drug Del. Rev. 1999, in press.

8. Tsuji, A.; Takanaga, H.; Tamai, I.; Terasaki, T. Transcellular transport of benzoic acid across Caco-2 cells by a pH-dependent and carrier-mediated transport mechanism. Pharm. Res. 1994, 11, 30-37.

9. Poole, R. C.; Halestrap, A. P. Transport of lactate and other monocarboxylates across mammalian plasma membranes. Am. J. Physiol. 1993, 264, C761-C782.

10. Roth, D. A.; Brooks, G. A. Lactate transport is mediated by a membrane-bound carrier in rat skeletal muscle sarcolemmal vesicles. Arch. Biochem. Biophys. 1990, 279, 377-385.

11. Price, N.T.; Jackson, V.N.; Halestrap, A.P. Cloning and sequencing of four new mammalian monocarboxylate transport (MCT) homologues confirms the existence of a transporter family with an ancient past. Biochem. J. 1998, 329, 321-328.

12. de la Torre, A. SR; Serrano, M.A.; Alvarado, F.; Medina, J.M. Carrier-mediated L-lactate transport in brush border membrane vesicles from rat placenta during late gestation. Biochem. J. 1991, 278 (Pt 2), 535-541. 
13. de la Torre, A. SR; Serrano, M.A.; Medina, J.M. Carrier-mediated beta-Dhydroxybutyrate transport in brush-border membrane vesicles from rat placenta. Pediatr. Res. 1992, 32, 317-323.

14. Balkovetz, D.F.; Leibach, F.H.; Mahesh, V.B.; Ganapathy, V. A proton gradient is the driving force for uphill transport of lactate in human placental brush-border membrane vesicles. J. Biol. Chem. 1988, 263, 13823-13830.

15. Carstensen, M.H.; Leichtweiss, H.P.; Schroder, H. Lactate carriers in the artificially perfused human term placenta. Placenta 1983, 4, 165-174.

16. Liu, F.; Soares, M.J.; Audus K.L. Permeability properties of monolayers of the human trophoblast cell line BeWo. Am. J. Physiol. 1997, 273, C1596-C1604.

17. A. Van der Ende, A du Maine, A. L. Schwartz, and G. J. Strous. Modulation of transferrin-receptor activity and recycling after induced differentiation of BeWo choriocarcinoma cells. Biochem. J. 1990, 270, 451-457.

18. Prasad, P. D.; Hoffmans, B. J.; Moe, A. J.; Smith, C. H.; Leibach, F. H.; Ganapathy, V. Functional expression of the plasma membrane serotonin transporter but not the vesicular monoamine transporter in human placental trophoblasts and choriocarcinoma cells. Placenta 1996, 17, 201-207. 
19. Adson, A.; Raub, T.J.; Burton, P.S.; Barsuhn, C.L.; Hilgers, A.R.; Audus, K.L.; Ho, N.F.H.

Quantitative Approaches to Delineate Paracellular Diffusion in Epithelial Cell Culture Monolayers. J.

Pharm. Sci. 1994, 83, 1529-1536.

20. Yamaoka, K.; Tanigwara, Y.; Nakagawa, T.; Uno, T. A pharmacokinetic analysis program (MULTI) for microcomputer. J. Pharmacobio-Dyn. 1981, 4, 879-885.

21. Lankas, G.R.; Wise, L.D.; Cartwright, M.E.; Pippert, T.; Umbenhauer, D.R. Placental Pglycoprotein deficiency enhances susceptibility to chemically induced birth defects in mice. Reprod. Toxicol. 1988,12, 457-463.

22. Dancis, J.; Liebes, L. Drug delivery during pregnancy: Evaluation in vitro of new drugs. Reprod. Fertil. Dev., 1995, 7,1485-1489.

23. Audus, K.L. Controlling drug delivery across the placenta. Eur. J. Pharm. Sci., 1999, 8, in press.

24. Johnson, R.F.; Herman, N.L.; Johnson, H.H.; Arney, T.L.; Paschall, R.L.; Downing, J.W. Effects of fetal pH on local anesthetic transfer across the human placenta. Anesthesiology 1996, 85, 608-615. 
Utoguchi, N., Magnusson, M., and Audus, K.L. (1999) Carrier-mediated transport of monocarboxylic acids in BeWo cell monolayers as a model of the human trophoblast. J. Pharm. Sci. 88, 1288-1292. PMID: 10585224. Publisher's official version: <http://dx.doi.org/10.1021/js990173q> . Open Access version: http://kuscholarworks.ku.edu/dspace/.

25. Garcia, C.K.; Brown, M.S.; Pathak, R.K.; Goldstein, J.L. cDNA cloning of MCT2, a second monocarboxylate transporter expresed in different cells than MCT1. J. Biol. Chem. 1995, 270, 1843-1849. 


\section{Figure Legends}

Figure 1. Time course of $\left[{ }^{14} \mathrm{C}\right]$ benzoic acid uptake by BeWo cells. The vertical bar through each point represents the SD for four replicate experiments.

Figure 2. Concentration dependency of $\left[{ }^{14} \mathrm{C}\right]$ benzoic acid uptake by BeWo cells. The uptake of $\left[{ }^{14} \mathrm{C}\right]$ benzoic acid by BeWo cells was measured at $37^{\circ} \mathrm{C}$ for $30 \mathrm{~s}$. The upper dotted line represents the uptake for the saturable component calculated from the kinetic parameters obtained as described in the text. The lower dotted line represents the uptake for the nonsaturable component calculated from the kinetic parameters. The vertical bar through each point represents the SD of four replicate experiments.

Figure 3. $\mathrm{pH}$ dependence of $\left[{ }^{14} \mathrm{C}\right]$ benzoic acid uptake by BeWo cells. The uptake of $\left[{ }^{14} \mathrm{C}\right]$ benzoic acid by BeWo cells was determined at the indicated $\mathrm{pH}$ at $37^{\circ} \mathrm{C}$. The vertical bar through each point represents the SD of four replicate experiments. 
Figure 4. Lineweaver-Burk plots for: A) The concentration-dependent uptake of $\left[{ }^{14} \mathrm{C}\right]$ benzoic acid by BeWo cells. Uptake was measured in the absence (open circles) or presence of $2 \mathrm{mM}$ acetic acid (closed circles). B) The concentration-dependent uptake of $\left[{ }^{14} \mathrm{C}\right]$ acetic acid by BeWo cells. Uptake was measured in the absence (open triangles) or presence of $2 \mathrm{mM}$ benzoic acid (closed triangles). C) The concentrationdependent uptake of $\left[{ }^{14} \mathrm{C}\right]$-L-lactic acid by BeWo cells. Uptake was measured in the absence (open circles) or presence of $2 \mathrm{mM}$ benzoic acid (closed circles). D) The concentration-dependent uptake of $\left[{ }^{14} \mathrm{C}\right]$ benzoic acid by BeWo cells. Uptake was measured in the absence (open circles) or presence of $2 \mathrm{mM}$ L-lactic acid (closed circles). The vertical bar through each data point in the figures represents the SD of four replicate experiments. 
Table 1. Effects of metabolic inhibitors, ionophore (carbonylcyanide $p$ trifluoromethoxyphenylhydrazone; FCCP), anion-exchange (4,4'diisothiocyanostilbene-2,2'-disulfonic acid; DIDS) inhibitors, and sodium-depleted buffer on $\left[{ }^{14} \mathrm{C}\right]$ benzoic acid uptake by BeWo cell monolayers at $37^{\circ} \mathrm{C} .{ }^{a}$

\begin{tabular}{|l|c|c|}
\hline Inhibitor & Concentration & $\begin{array}{c}\text { Relative Uptake } \\
\text { (Percent of Control) }^{\mathbf{b}}\end{array}$ \\
\hline Sodium azide & $10 \mathrm{mM}$ & $20.1 \pm 5.2^{*}$ \\
2,4-Dinitrophenol & $1 \mathrm{mM}$ & $13.3 \pm 7.4^{*}$ \\
FCCP & $50 \mu \mathrm{M}$ & $9.3 \pm 1.4^{*}$ \\
DIDS & $100 \mu \mathrm{M}$ & $117.5 \pm 8.1$ \\
Sodium-depleted buffer & No treatment & $101.7 \pm 11.7$ \\
\hline
\end{tabular}

a BeWo cells were pretreated with these agents for 15 min prior to performing an uptake experiment.

b Each value represents the mean \pm standard deviation of four experiments.

* $\quad \mathrm{P}<0.001$ versus untreated control $(100 \%)$. 
Table 2. Effects of selected carboxylic acids on $\left[{ }^{14} \mathrm{C}\right]$ benzoic acid or $\left[{ }^{14} \mathrm{C}\right]$ acetic acid uptake by BeWo cell monolayers at $37^{\circ} \mathrm{C} .^{a}$

\begin{tabular}{|llcr|}
\hline & & \multicolumn{2}{c|}{$\begin{array}{c}\text { Relative uptake } \\
\text { (Percent of control) }\end{array}$} \\
& & $10.8 \pm 0.2^{*}$ & $19.5 \pm 2.7^{*}$ \\
Monocarboxylic acids & Benzoic acid & $20.4 \pm 1.8^{*}$ & $26.5 \pm 4.2^{*}$ \\
& D-Lactic acid & $6.1 \pm 1.3^{*}$ & $13.4 \pm 1.5^{*}$ \\
& L-Lactic acid & $12.7 \pm 0.9^{*}$ & $18.9 \pm 2.6^{*}$ \\
& Propionic acid & $10.1 \pm 2.0^{*}$ & $36.9 \pm 2.9^{*}$ \\
& Acetic acid & $5.5 \pm 0.1^{*}$ & $20.7 \pm 3.4^{*}$ \\
& p-Aminobenzoic acid & $12.3 \pm 1.3^{*}$ & $11.1 \pm 1.0^{*}$ \\
& Acetylsalicylic acid & $3.5 \pm 0.1^{*}$ & $9.3 \pm 0.7^{*}$ \\
& Salicylic acid & & \\
Dicarboxylic acids & Glutaric acid & $91.0 \pm 8.5$ & $107.2 \pm 12.8$ \\
& Fumaric acid & $113.8 \pm 5.5$ & $98.4 \pm 10.4$ \\
& Maleic acid & $92.1 \pm 7.3$ & $102.4 \pm 28.4$ \\
\hline
\end{tabular}

a $\quad\left[{ }^{14} \mathrm{C}\right]$ benzoic acid or $\left[{ }^{14} \mathrm{C}\right]$ acetic acid uptake by BeWo cells were performed in the presence of $10 \mathrm{mM}$ (2000-fold excess) of the indicated carboxylic acid.

b Each value represents the mean \pm standard deviation of four experiments.

* $\quad P<0.001$ versus untreated control $(100 \%)$. 
Table 3. Lineweaver-Burke uptake and inhibition constants for monocarboxylic acid uptake by BeWo cell monolayers at $37^{\circ} \mathrm{C}$.

\begin{tabular}{|lcccc|}
\hline & $\mathbf{K}_{\mathbf{m}}(\mathbf{m M})^{\mathbf{b}}$ & $\begin{array}{c}\text { Benzoic acid } \\
\mathbf{K}_{\mathbf{i}}(\mathbf{m M})^{\mathbf{b}}\end{array}$ & $\begin{array}{c}\text { Acetic Acid } \\
\mathbf{K}_{\mathbf{i}}(\mathbf{m M})^{\mathbf{b}}\end{array}$ & $\begin{array}{c}\text { Lactic Acid } \\
\mathbf{K}_{\mathbf{i}}(\mathbf{m M})^{\mathbf{b}}\end{array}$ \\
${ }^{{ }^{14} \text { C]Benzoic } \text { acid }^{\mathbf{a}}}$ & $1.0 \pm 0.1$ & - & $1.1 \pm 0.2$ & $0.7 \pm 0.3$ \\
${ }^{14}$ C]Acetic acid & $0.8 \pm 0.2$ & $0.8 \pm 0.3$ & - & - \\
${ }^{14}$ C] Lactic acid $^{\mathbf{a}}$ & $1.4 \pm 0.2$ & $0.7 \pm 0.2$ & - & - \\
\hline
\end{tabular}

a $\quad\left[{ }^{14} \mathrm{C}\right]$ benzoic acid or $\left[{ }^{14} \mathrm{C}\right]$ acetic acid or $\left[{ }^{14} \mathrm{C}\right]$ lactic acid uptake by BeWo cells were performed alone and in the presence of $2 \mathrm{mM}$ (1 to 8-fold excess) of the indicated monocarboxylic acid.

b Each value represents the mean \pm standard deviation of four experiments. 
Table 4. Apparent permeability coefficients for the passage of $\left[{ }^{14} \mathrm{C}\right]$ benzoic acid across BeWo cell monolayers at $37^{\circ} \mathrm{C}$.

\section{Direction of benzoic acid permeation across monolayer}

Apical to basolateral

Basolateral to apical
Permeability Coefficient (x $\left.10^{3} \mathrm{~cm} / \mathrm{sec}\right)$
$4.90 \pm 1.01$

$0.45 \pm 0.04^{*}$

$0.64 \pm 0.21^{*}$

$1.06 \pm 0.70^{*}$

a $\quad\left[{ }^{14} \mathrm{C}\right]$ benzoic acid permeation across BeWo cell monolayers was performed in the presence of $10 \mathrm{mM}$ (2000-fold excess) of the indicated carboxylic acid in the apical chamber.

* $\quad \mathrm{P}<0.001$ versus untreated benzoic acid permeation apical to basolateral. 